Article

\title{
Towards a Framework for Understanding Discursive Regime Destabilisation: A Case Study of a Social Movement Organisation "Economy for the Common Good"
}

\author{
Olga Vincent ${ }^{1, *(\mathbb{D})}$ and Christian Scholl ${ }^{2}$ \\ 1 Copernicus Institute of Sustainable Development, Utrecht University, 3584 CB Utrecht, The Netherlands \\ 2 International Centre for Integrated Assessment and Sustainable Development, Maastricht University, \\ 6200 MD Maastricht, The Netherlands \\ * Correspondence: o.koretskaya@uu.nl
}

Received: 9 May 2019; Accepted: 8 August 2019; Published: 13 August 2019

\begin{abstract}
Despite increasing scepticism about the conventional growth model, the topic of destabilisation of socio-economic regimes has not yet captured scholarly interest. This paper addresses this gap and serves a twofold purpose. First, it develops an analytical framework for studying discursive regime destabilisation based on previous research by Turnheim and colleagues. The framework is novel as it allows for: (1) structured analysis of framing interactions between niche and regime actors; (2) visualised mapping of discursive actors; and (3) identification of phases of discursive destabilisation. Second, the paper contributes to the literature on an ongoing practice of socio-economic transformations by applying the framework to a case study of a social movement organisation, "Economy for the Common Good" (ECG), that seeks to advance socio-economic transition. The suggested framework was useful for analysing the ECG. First, it demonstrated that niche actors employed mostly motivational and prognostic frames supporting the alternative economic approach, while the regime diffused mostly diagnostic frames focusing on the perceived negative aspects of the niche. Second, by applying the framework, we identified three relevant destabilisation phases in this socio-economic transformation process: Blindness and Denial, Incremental Responses to Problems and Increasing Doubts and Diversification. We argue that the framing of the niche affects different actor groups differently: while representatives of high authorities remained in the first phase of destabilisation, regional authorities and private companies already appeared at the second and third phases.
\end{abstract}

Keywords: multi-level perspective; socio-economic transformation; destabilisation; framing analysis; social movement organisations; Economy for the Common Good

\section{Introduction}

Practices embedded in the established socio-economic regime of capitalism have led to grave environmental and social problems such as climate change, loss of biodiversity, plastic pollution and rising inequality [1-3]. In academic debates, scepticism about the conventional growth model has been present for decades. Most recently, the field of degrowth studies has been paying considerable attention to a systemic critique of growth-based economies and, at the same time, to the quest for alternatives [4,5]. However, there is still "no specially devoted research tradition" on the topic of the socio-economic transformation that addresses, among other issues, the growth paradigm, market institutions, and economic diversity [6]. 
Concurrently, in the field of transition studies, a useful multi-level perspective (MLP) framework (with explicit focus on change processes) has been developed for studying socio-technical transitions [7-11] that entail changes in technologies, policy, markets, and cultural meanings [12]. Economic conditions and values are considered there as a part of the landscape or selection environment. More recent studies have shown, however, that capitalism is not just a landscape factor: it defines the workings of socio-technical systems and can influence the sustainability of transition outcomes [13]. The failure of sustainability transition research to engage with capitalism [13] therefore has serious implications for the empirical value of transition studies, as well as the insights it could deliver for society and policymaking. Vandeventer et al. [14] recently made the first attempt to extend the MLP to socio-economic transformations and conceptualise the capitalist, growth-oriented economic system as a regime. In this paper, we continue this line of work by shedding light on a process that has generally been absent in transition studies [15], but is critical for achieving systemic changes: regime destabilisation. Drawing on Vandeventer et al. [14], we test whether destabilisation theory can be usefully applied to socio-economic transformations, thus stretching the potential of transition studies.

It is important to note here that the terms "transformation" and "transition" are not strictly defined in the literature. The former is usually applied to socio-ecological systems, while the later to socio-technical systems. In transition theory, the terms are not always distinguished [16]. In this paper, both concepts are used to mean a structural change of the system. Destabilisation in this context is an integral part of transformation/transition processes.

To our knowledge, the topic of unlocking or destabilising socio-economic regimes has not yet been explored in peer-reviewed publications, which is a surprising mismatch between the identified limitations of the current economy and the scope of future ambitions. In socio-technical studies, destabilisation has been gaining more attention in recent years (e.g., [16-18]), but is still considered to be an understudied topic [15]. Destabilisation is defined as "the process of weakening reproduction of core regime elements" [19], and unfolds in five core phases (see Section 3). Little is known, however, about how these phases develop and progress from one to the next, as well as the factors that hinder or foster such processes [20]. Kuokkanen et al. [21] suggest that discursive competition, alignment and misalignment of actors can influence regime destabilisation, and Bosman et al. [22] argue that discursive destabilisation can precede the destabilisation of actual practices. Göpel [23] claimed that dominant ideas and discourses, which translate them, deeply influence both regime and niche developments, therefore having profound effect on sustainability transformations. Although these claims require further testing, they suggest that the discursive approach to the study of the unlocking of regimes deserves attention.

The discursive approach allows one to trace how the contestation of regimes is a process of social construction of a broad variety of actors drawn into the emerging conflict. It also uncovers how the "the struggle for heart and minds" is a struggle for hegemony [24]. Analysis of the growth-oriented regime through the lens of discursive destabilisation can be especially fruitful as the growth paradigm was shown to be a cognitive framework in which the growth imperative is perceived as positive and necessary [25]. Questioning whether GDP is a useful indicator for socio-economic development thus becomes a political and cultural project that de-mystifies the economy as a domain of professional experts and opens it up to common people [26].

A discursive approach has been employed in transition studies only recently, and it has provided insight into different types of frames, negotiation processes among competing interests [27] and the development of storylines based on four elements of frame resonance [28]. Framing analysis and the concept of destabilisation, however, hold greater potential for integration. For instance, frames can be used as a litmus test for unfolding destabilisation processes due to the fact that transition actors construct meanings through frames by emphasising some aspects of an issue and omitting others [29].

This paper has a twofold purpose. First, it develops a novel analytical framework for studying discursive regime destabilisation based on work by Turnheim and Geels [19] and Rosenbloom [27]. The framework adds to the existing literature in the following ways: (1) it allows for a structured 
analysis of strategic framing employed by different niche and regime actors; (2) it can be used for visually mapping actors of discourse; and (3) it helps identify phases of discursive destabilisation. Second, the paper contributes to the literature on socio-economic transformations by applying the framework to a case study of a social movement organisation, "Economy for the Common Good" (ECG), that seeks to advance socio-economic transformation.

In what follows, we first introduce the case study and research design, and then outline the main theoretical concepts and provide a detailed explanation of our framework. The results of the case study are presented in the form of the key frames for niche and regime and their juxtaposition. In the Section 4, we analyse the unfolding discursive destabilisation phases. In the Section 5, we offer key implications for policy and research.

\section{The Case of the ECG and Research Design}

The analytical framework developed in this paper is applied to a case study of the ECG, a social movement organisation (SMO) that aims to contribute to socio-economic transformation. Social movements (SM) often play an important role in challenging political and economic authorities [30,31] as they announce the existence of a problem in a certain area [32] and produce new knowledge to transform society [33]. In the language of transition studies, SMs are carriers of social innovations. The concept of SMOs is used to differentiate between the totality of diverse, polycentric and often fuzzy networks making up SMs and organisations with some degree of formalisation that seek to represent the SMs as a whole [34]. Due to the combination of social innovation character and small-scale functioning, SMOs can be conceptualised as niches in accordance with the definition used in transition studies [35].

The ECG is defined as an SMO, because it is a complex, constantly growing organisation with concrete goals and strategies to achieve them [36]. The ECG's history starts in 2010, when Christian Felber, co-founder of the ECG, published the book Economy for the Common Good and, together with 15 entrepreneurs, took the Common Good Balance Sheet (CGBS) - a tool for sustainable reporting-to the public. In 2011, the first local "chapters" (i.e., "networks of people who play active roles in the overall movement" [37]) were established. By 2018, the ECG was supported by 400 companies (mostly small and medium enterprises) and it currently has over 100 local chapters worldwide, the majority of which are concentrated in Europe and Latin America [38].

The ECG's main critique is directed towards capitalism, an economic system governed by the rules of a game in which capital accumulation and profit maximisation are prioritised (in public discussions, niche actors often refer to "capitalism" as the "current economic system"; both terms are therefore used interchangeably here). The ECG is not the only niche that strives to create alternatives to the capitalist-growth regime. Other niches could include, for instance, degrowth, steady state economy or post-growth [14], all of which are organised around a critique of neoliberal theory that, for some time, has been the dominant paradigm at most universities' economics departments and business schools, but is more recently being complemented by institutional, feminist, social and ecological economics theories, among others [39].

The ECG argues that the current economic system creates a wide range of problems, including intraand intergenerational inequality, social exclusion and environmental degradation [40]. The solution that ECG offers is a new, value-based economic model designed to pursue the common good-and not profit—as an ultimate goal. The notion of the common good implies that:

Inequalities in income, wealth and power are kept to a minimum. Consumption of natural resources remains within the regenerative capacity of natural ecosystems and planetary boundaries. Current and future generations enjoy equal opportunities (... ) Our relationship with the earth is healthy as is the earth itself. [41]

The ECG's actions are centred on two main purposes: to change informal and later formal rules. The CGBS is one of the ECG's main tools, and the goal is to make it a unified, obligatory standard for 
reporting that would complement and eventually replace the current commonly used financial balance sheet [40]. The CGSB attempts to capture comprehensively the ethical and sustainability aspects of all economic activities of an organisation. It is designed to provide a public account of the degree to which an organisation commits to and implements social, economic and environmental sustainability. The ECG supports the adaptation and implementation of the CGBS by giving public talks, offering practical support and creating a transnational network, among other activities. By voluntary publishing the outcomes of the CGBS, private companies, NGOs or public institutions are also expected to play a role in raising awareness among other organisations and consumers about sustainability issues. A long-term goal for the ECG is to develop a Common Good Product to replace the Gross Domestic Product. This indicator would be based on the same values as the CGBS and would also account for three pillars of sustainability [40].

ECG representatives and supporters consider the CGBS different from other sustainability assessment tools like Global Reporting Initiative (GRI) or Global Compact. In a personal communication (20 May 2018), business consultant and active ECG member Marta Avesani explains that
"(o)ther standards are managerial, which means that they are meant to decrease risks in the organisation and help the business to be economically sustainable and exist in the long-term, while the ECG is more radical or strong. It says that if your product is harmful to the planet and people, you should stop. GRI or Global Compact will never say something similar, as they protect organisations. GRI and others, they still keep profit as a goal".

The frame analysis for the chosen case study of socio-economic transition in the making was performed based on media sources, documents, interviews and a survey. First, media articles published in the LexisNexis database in the last seven years in English and German were analysed. English was chosen because articles published in this language ensure international coverage of the movement, German because the ECG originates in Austria and has been very active in German-speaking countries. For feasibility reasons, only articles explicitly mentioning the ECG were included in the analysis. The search identified 23 relevant articles in English and 246 articles in German. Some articles were "guest comments" - that is, the entire piece was written by a niche or a regime representative. Some articles were written by journalists, but the chosen claims were always part of a direct citation. In this way, we sought to avoid the influence of journalists' interpretation of our analysis of framing processes.

A document analysis was performed to complement the newspaper analysis. From the niche side, nine documents were studied, among which were Christian Felber's book Change Everything. Creating an Economy for the Common Good [40]; Workbook Full Balance Sheet 5.0 [42]; the summary of the ECG's ideas in Gemeinwohl-Ökonomie. Eine demokratische Alternative wächst [43]; and responses from the ECG and Christian Felber to the petition from the Austrian economists [44]. From the regime side, five documents were studied, including a report by the Austrian Chamber of Commerce [45], think-tank reports [46] and a petition by Austrian economists [47]. In seven semi-structured interviews with ECG members and organisations that voluntarily implemented the CGBS, we further explored preliminary frames and their respective claims in more detail. A web-based survey (including both open- and closed-ended questions) sent out to 200 organisations that had adopted the CGBS returned a low response rate (15 valid responses), these insights were used to complement data from media and document analysis, and to reflect on the dynamics within the discourse. Different sources of data allowed us to capture both a big picture of the discourse around the ECG and a more detailed understanding. The data were analysed in an iterative process of in-depth reading, coding, clustering and interpretation. Through these iterative rounds, we made sure that all data were accurately captured by coherent frames and the respective key claims they transport. In the case of too much overlap between two frames, we tried to integrate them, and in case of too much divergence within one frame, we considered a new one. 


\section{Towards a Framework for Understanding Regime Destabilisation through Strategic Framing Interaction}

In the transition literature, attention is predominantly paid to the development of niches and their interaction with regimes $[11,48]$. According to the widely used definitions, regimes consist of largely accepted rules, the incumbent actors that follow them and a shared vision of the future, while niches represent protective spaces within which disruptive innovations emerge [9,49]. Socio-technical regimes are not monolithic; on the contrary, they are subject to power and framing struggles $[8,50]$. We suggest that the same assumptions hold true for socio-economic regimes.

Niches and regimes can co-exist and mutually influence each other [51]. This influence (either negative or positive) can be exerted by actors who might have nothing in common or who might belong to several arrangements at once. For this reason, it is important to differentiate between different types of actors. Drawing on Geels [52], Rosenbloom et al [53], we suggest distinguishing between core and aligned regimes and niche actors (see Figure 1). The former are committed to the arrangement they represent, support its stability by constantly reproducing its elements and can influence others to follow their rules. The latter do not show a clear commitment to a specific regime or niche, can deviate from the rules and support elements of several regimes and/or niches at the same time.

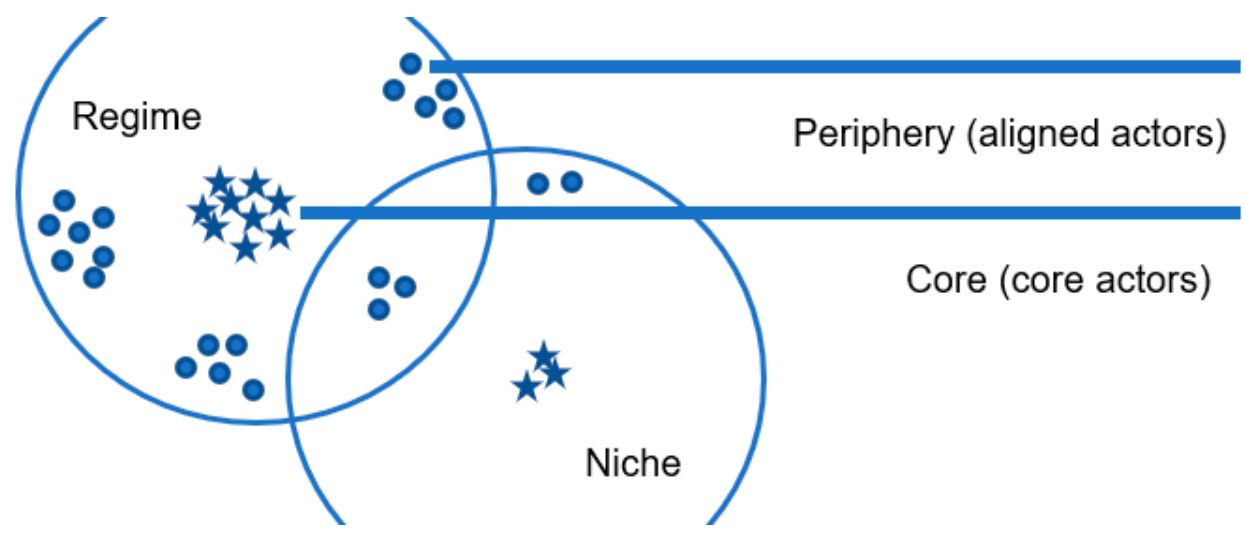

Figure 1. Core and aligned actors, based on Geels (2014a) and Rosenbloom, Berton, and Meadowcroft (2016). Dots symbolise aligned actors, and stars represent core actors.

Transitions take place if niche actors overcome regime pressures and the niche manages to grow into a new dominant regime [11]. Destabilisation, which is an important part of these processes, unfolds in parallel to them in the following phases [19]:

1. Blindness and denial. Incumbent actors have strong regime commitments and deny performance problems. External pressure is weak.

2. Incremental responses to problems. Regime actors recognise performance problems due to increased external pressure, but they still have strong commitments and respond by incremental innovation strategies.

3. Increasing doubts and diversification. Incumbents doubt at least some elements of the existing regime and explore solutions outside it.

4. Decline and destabilisation. At this phase, problems become too big and result in crises that make incumbents lose their commitment to the regime and adopt radical innovations. In the reorientation sub-phase, actors look for new means to adapt to changing knowledge or regulations. In the re-creation sub-phase, actors re-invent hopes for survival as changes occur on the level of mission or core beliefs.

5. Dissolution. This phase occurs if reorientation and re-creation fail. Incumbent actors decline.

We suggest that these phases can be applied to discursive destabilisation. By doing so, we achieve a more coherent and structural approach to the analysis of discursive destabilisation and 
create a foundation for further integration of discursive dynamics and the destabilisation of routines and practices.

Frames can have three distinct functions: diagnostic, prognostic and motivational. Drawing on Snow and Benford [54], Geels [50] suggested using this distinction in transition studies. Diagnostic framing defines a problem; prognostic framing offers solutions; and motivational framing provides reasons for taking a certain action. These functions clearly show how frames are results of shared socially constructed meanings [55] and are used to identify problems, attribute blame and create "corresponding sense of responsibility for corrective action" [54]. Categorising the niche and regime frames in our case study according to these three functions also enables deeper analysis of the process of framing interaction. Not only does it show which types of frames are most commonly used, but also how (with what type of frame) the regime reacts to a specific type of niche frame, and vice versa.

To this end, we employ an approach suggested by Rosenbloom et al. [53] contrasting legitimising and de-legitimising storylines and attributing claims to specific actors. This approach is combined with the three framing functions [50] and the concept of core/aligned actors [52,53] in an analytical matrix (see Table 1). The frames for the regime and niche are formulated on the basis of key claims made by both core and aligned actors. The arrows symbolise the types of frames: blue for motivational frame, green for prognostic frame or red for diagnostic frame. "Clashing" arrows do not necessarily mean that actors respond directly to each other's key claims (transported through the frames). This "clashing" rather symbolises discursive incongruence.

Table 1. Analytical matrix for framing analysis. The arrows indicate the types of frames: blue for motivational frame, green for prognostic frame or red for diagnostic frame.

\begin{tabular}{|c|c|c|c|c|c|c|c|}
\hline $\begin{array}{c}\text { Aligned } \\
\text { Actors }\end{array}$ & $\begin{array}{l}\text { Core } \\
\text { Actors }\end{array}$ & $\begin{array}{c}\text { Key } \\
\text { Claims }\end{array}$ & $\begin{array}{l}\text { Regime's } \\
\text { Frame }\end{array}$ & $\begin{array}{l}\text { Niche's } \\
\text { Frame }\end{array}$ & $\begin{array}{l}\text { Key } \\
\text { Claims }\end{array}$ & $\begin{array}{l}\text { Core } \\
\text { Actors }\end{array}$ & $\begin{array}{c}\text { Aligned } \\
\text { Actors }\end{array}$ \\
\hline
\end{tabular}

Using the analytical matrix as a basis, we further suggest visually mapping core and aligned actors and connecting the maps with discursive destabilisation phases. This provides a snapshot of all unfolding phases at the given time in one glimpse (see Figure 2). Actors in the first phase of discursive destabilisation would be situated in the regime's core, as they have strong commitments manifested through exclusive reproduction of frames that reinforce the status quo. Actors in the second phase would reproduce both frames that reinforce the regime and that doubt it, so they would be situated in the regime's periphery. Actors in the third phase of discursive destabilisation would reproduce frames that support solutions outside the regime and belong to one of the niches, although their continuous commitment to the regime would still make them belong to the regime's periphery. This means that regime actors undergoing the third phase would be situated in the space of mutual alignment between the regime and the niche. If former regime actors happen to be situated in a niche's core or periphery (i.e., they reproduce frames that support one or more niches), this means they are undergoing the fourth phase of discursive destabilisation. During the fifth phase, regime actors decline, so this phase is not represented.

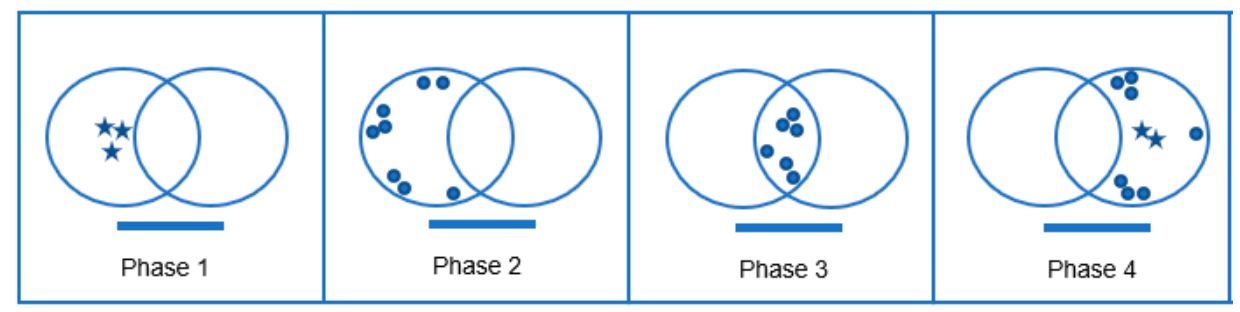

Figure 2. Integrating destabilisation phases and the framing analysis, based on Geels (2002; 2014b) and Rosenbloom et al. (2016). Stars represent core actors and dots represent aligned actors. 


\section{Applying the Framework to the ECG Case Study}

Based on the media and document analysis, regime and niche actors were identified. Because of the limited range of studied articles, we acknowledge that these represent only a fraction of the regime and niche actors involved in the framing interaction with the ECG. The list (see Appendix A) is by no means exhaustive. The regime is represented by profit- and growth-oriented entities, such as business associations, think tanks, state institutions and their representatives. Although they all have to follow the same rules and regulations, these are not a homogeneous group of actors. When regime actors expressed viewpoints contradicting the growth-centred cognitive framework, we classified them as regime aligned actors. We applied the same logic for the niche: all identified core actors showed commitment to the specific niche and supported its diffusion and development, while all identified aligned actors did not demonstrate an exclusive commitment to the ECG and supported several competing socio-economic innovations.

\subsection{Niche Frames}

Our case study identified six niche frames. An overview is presented in Table 2 and an extended summary appears in Appendix B.

Table 2. Summary of niche framing.

\begin{tabular}{lll}
\hline \multicolumn{1}{c}{ Niche Frame } & & \multicolumn{1}{c}{ Key Claims } \\
\hline Malfunctioning Economic & - & The current economic system creates many problems \\
System & - & Neoliberal capitalism is not aligned with what people want \\
\hline \multirow{2}{*}{ Ethical Economy } & - & Wealth is unevenly distributed \\
\hline \multirow{2}{*}{ New Market Economy } & - & Enterprises must take responsibility for their actions \\
& - & The economy should be based on universal values \\
\hline Useful Sustainability & - & ECG calls for a new economic system that is a consistent alternative to \\
Reporting & - & CGG does not fall back into the extremes of capitalism and communism \\
\hline \multirow{2}{*}{ Expression of Public Will } & - & CGBS enables any organisation to evaluate its impact \\
\hline \multirow{2}{*}{ Economic Opportunity } & - & CGBS could help to implement the UN Sustainable Development Goals \\
\hline
\end{tabular}

\subsubsection{Malfunctioning Economic System}

This is a diagnostic frame that states a problem that the ECG wants to address. Core and aligned niche actors point out systemic errors of neoliberal capitalism that cause problems such as inequality and pollution. The main idea of the first ECG frame is captured by Matt Mayer, director of the ECG UK: "The current economic system is not aligned with what we, humans, want in our lives and for the world" (personal communication, 20 May 2018). This is the only frame that gets support from regime actors who criticise the ECG; Dirk Löhr, German economist, and Erhard Fürst, ex-chief economist of the Austrian Federation of Industrialists, for example, also claim that the current system has many systemic problems.

\subsubsection{Ethical Economy}

The second frame is prognostic, as it offers a solution: changing the purpose of the economic system from financial gain to universally accepted values of appreciation of people and nature. These values are more specifically defined by core ECG actors as dignity, solidarity, ecological sustainability, social 
justice, transparency and democracy. Aligned niche actors such as Vaude, Sparda-Bank Munich, Greenpeace, and "green" politicians do not necessarily use these terms, but emphasise how vital it is to incorporate non-financial values into business and institutional practices.

\subsubsection{New Market Economy}

This is also a prognostic frame that pictures the ECG as a new economic alternative. Members of the ECG do realise that ideas with left-wing elements face a certain type of criticism: "Everyone who challenges the current system can be denounced as Marxist or communist. There is a challenge in the word 'common good'" (A. Winchenbach, personal communication, 15 May 2018). The ECG separates itself from communism and Marxism by underlining its compatibility with the market economy. The European Economic and Social Committee (EESC), which was categorised as a regime actor, also supports this claim by arguing that "the ECG is a model to be realised within the market economy, it is not opposed to the market economy" [56]. Niche actors, however, clearly separate themselves from the neoliberal capitalist regime and underline the innovative character of the ECG. For example, a book by Christian Felber has the title Change Everything: Creating an Economy for the Common Good, and ECG's slogan reads "an economic model for the future" [41]. Both core and aligned niche actors argue that the ECG develops a new economic system based on market principles.

\subsubsection{Useful Sustainability Reporting}

This is the last prognostic frame. It is based on the claims that the CGBS helps companies to perform self-assessment, plan their future development and be more transparent. This frame is often reproduced by aligned niche actors, mostly by companies who voluntarily choose to implement the CGBS (e.g., Sparda-Bank Munich; Sonnentor; Business School Lausanne; Vaude). The EESC also endorses the CGBS, saying that "the CGBS measures the most important constitutional values: dignity, solidarity, sustainability, justice, and democratic participation: "ethical performance" vis-à-vis all the contact groups" [56].

\subsubsection{Expression of Public Will}

The fifth identified frame is motivational, as it explains a rationale behind the suggested solutions. Key claims supporting this frame state that people already want a different, more ethical system. This desire is manifested through the results of various opinion polls, a growing number of social enterprises, as well as doubts about the usefulness of GDP as a measurement of countries' economic performance. The CGBS is also presented in this frame as a tool that can help to achieve UN Sustainable Development Goals, which manifest international will to build a more fair and ethical society.

\subsubsection{Economic Opportunity}

The last identified niche key frame can also be categorised as motivational. The ECG is framed as an economic opportunity. According to core and aligned niche actors, the ECG will create jobs and beneficial conditions for small and medium enterprises. According to ECG supporters, businesses can thrive as long as their activities are serving the common good and treat money as a tool rather than a goal. The ECG's view on economic growth is also explained in this frame:

"We don't want material growth, i.e., that we use more resources from the planet because it's not sustainable. But we don't necessarily need economic de-growth. If we have an economy that works in an ethical way, we can still have financial growth". (M. Mayer, personal communication, 20 May 2018)

Our analysis suggests that all three types of framing categorisation are present here, with the main focus being placed on prognostic frames; this means that the niche actors are concentrated on providing solutions rather than on showing problems. The key frames reproduced by niche actors are 
consistent and form an integral picture. Core actors generally ensure this continuity and consistency; no major differences within their claims were identified in the framing analysis.

\subsection{Regime Frames}

Regime actors engage in discursive battles with niche actors by diffusing their messages through media, think-tank reports and governmental organisations. A short summary of seven frames and their key claims is presented in Table 3, while the extended summary appears in Appendix B.

Table 3. Summary of regime framing.

\begin{tabular}{|c|c|}
\hline Regime Frame & Key Claims \\
\hline \multirow{2}{*}{ Socio-Economic Progress } & - $\quad$ Enormous wealth has been created \\
\hline & Competition leads to growth and prosperity \\
\hline \multirow[t]{2}{*}{ Profit-Driven Economy } & $\begin{array}{l}\text { - } \quad \text { Motivated by profit, companies produce innovations with social and } \\
\text { environmental added value }\end{array}$ \\
\hline & Regulated self-interest or free markets create well-being \\
\hline \multirow{2}{*}{ Old Socialist Ideas } & ECG does not formulate a new alternative \\
\hline & - $\quad$ ECG packs the ideas of Marxism into new phrases \\
\hline \multirow{3}{*}{ Scientific Uncertainty } & ECG is based on normative statements \\
\hline & ECG has no sound theoretical background \\
\hline & ECG is based on a contradictory and very populist analysis \\
\hline \multirow{3}{*}{$\begin{array}{l}\text { Imposed Sustainability } \\
\text { Reporting }\end{array}$} & CGBS is far too regulatory \\
\hline & It is immensely complex accounting \\
\hline & The values of CGBS will be imposed on companies \\
\hline \multirow{3}{*}{$\begin{array}{l}\text { Common Good } \\
\text { Dictatorship }\end{array}$} & - $\quad$ ECG restricts freedom by suggesting maximum income \\
\hline & What should or should not be produced is determined from the top \\
\hline & - Minimisation of competition can lead to a "common good dictatorship" \\
\hline \multirow{3}{*}{ Business Threat } & CGBS increases the costs of doing business \\
\hline & Production processes will become inefficient and expensive \\
\hline & Austria will fall out of the international economic grid \\
\hline
\end{tabular}

\subsubsection{Old Socialist Ideas}

This frame is diagnostic because it identifies problems regarding the ECG. Key claims are that the ECG is repeating the ideas of Marxism and socialism and that it represents a new version of the centrally planned economy. Both core and aligned regime actors who support this frame challenge the ECG's messages about the innovative character of its ideas.

\subsubsection{Scientific Uncertainty}

Both core and aligned actors emphasise a lack of theoretical underpinnings for the ECG's ideas, implying that these ideas cannot be compared to the established "growth- and profit-oriented" economic science. Actors talk about ECG's inconsistency, its simplistic and populist analysis of the current situation, describing it with words such as "utopia" and "fantasy". Regime actors also argue that the value basis for the ECG and CGBS-human dignity, solidarity, sustainability, justice and democracy-are not sufficiently scientifically derived.

\subsubsection{Common Good Dictatorship}

This frame aims to debunk ECG's claims about its bottom-up nature and focus on universal values. Key claims centre on the idea of the ECG proposing a system with totalitarian elements. Coined by the president of the Austrian Economic Chamber, Harald Mahrer, the term "Common Good Dictatorship" suggests that the notion of common good is defined from above, and all entities 
(companies, institutions) have to conform regardless of their opinions [46]. German economist Dirk Löhr argues that a market economy should be free of privileges, but ECG suggests granting privileges to companies that score high in the CGBS, therefore defining what should be produced and how, thus slipping into "green totalitarianism" [57].

\subsubsection{Imposed Sustainability Reporting}

The sixth frame points out flaws of the CGBS. Companies tend to call the CGBS "radical", economists call it "bureaucratic" and even suggest a resemblance with practices in authoritarian systems. Actors who diffuse this frame also doubt that indicators included in the CGBS are objective and representative of what companies consider beneficial for themselves.

\subsubsection{Business Threat}

The seventh regime frame pictures the ECG as a threat to business. Both core and aligned regime actors diffuse this frame with the following key claims: ECG will lead to rising operational costs, decreased efficiency and loss of jobs due to complex accounting and a less hierarchical management structure. Actors also have concerns about competition, as less competition supposedly decreases the motivation for innovation and eventually may lead to monopolies and cartels.

\subsubsection{Socio-Economic Progress}

This frame is motivational as it provides reasons for preserving the current socio-economic order. The key claims are that neoliberal capitalism has brought innovation, wealth and prosperity and that it has the capacity to solve upcoming issues.

\subsubsection{Profit-Driven Economy}

This frame is also motivational, as it explains why profit is worth preserving as the main motivation for businesses and economies. It is similar in some respect to the previous frame, because it also emphasises the progress brought by profit-driven entities. The key difference is that the first frame justifies the entire neoliberal capitalist system with its internal rules and regulations (e.g., competition and deregulation), while the second frame justifies the underlying driver of all actors within the system (i.e., profit).

Core regime actors focus on de-legitimising the ECG, as five out of seven frames are diagnostic and target "problems" of the niche. The remaining two frames explain why the current economic system is good and why profit should be preserved as a key motivational factor. Voices within the regime's core are mostly coherent, as dominant frames are not mutually exclusive or contradictory. Core regime actors, however, do not diffuse any prognostic frames and do not offer any alternative solutions that would address the rising concerns within society.

\section{3. "Snapshot" of the Discourse}

Almost every frame diffused by regime actors is confronted with a frame diffused by niche actors (see Table 4). However, one regime frame, Scientific Uncertainty, remains unanswered at the moment. The ECG started working on a theoretically solid alternative to the current economic theory to avoid similar accusations of a lack of academic background (C. Felber, personal communication, 20 May 2018). Once completed, this work could inspire a new frame. 
Table 4. Framing struggles between the niche and the regime*.

\begin{tabular}{cc}
\hline Regime Frames & Niche Frames \\
\hline Socio-Economic Progress & Malfunctioning Economic System \\
Profit-Driven Economy & Ethical Economy \\
Old Socialist Ideas & New Market Economy \\
Scientific Uncertainty & No corresponding frame \\
Imposed Sustainability Reporting & Expression of Public Will \\
Common Good Dictatorship & Economic Opportunity \\
Business Threat & Eumostic (red) type.
\end{tabular}

Core niche actors have previously intentionally adjusted their discourse to counter critical regime frames and to reveal the wrong assumptions behind them (M. Mayer, personal communication, 20 May 2018; C. Felber, personal communication, 20 May 2018). For instance, in response to the Common Good Dictatorship and Business Threat frames, niche actors emphasised that the ECG was not against the market economy, competition or profit.

Overall, the niche's efforts are concentrated on creating a picture of a better alternative and explaining why it would work. Christian Felber summarised the framing strategy of the ECG:

"Our priority is to show a positive vision. The current system is disqualifying itself, it doesn't need to be fuelled by criticism. The best argument against something obsolete is to show the alternative. We show negative sides implicitly but not as a strategic focus". (personal communication, 20 May 2018)

To visualise the diffusion of actors throughout the regime's and niche's core and periphery, we used a detailed analytical matrix (see Appendix B) to create Figure 3. Based on the location of actors, we can further make conclusions about three unfolding discursive destabilisation phases in the case of the ECG: Blindness and Denial, Incremental Responses to Problems and Increasing Doubts and Diversification. They are discussed in the following section.

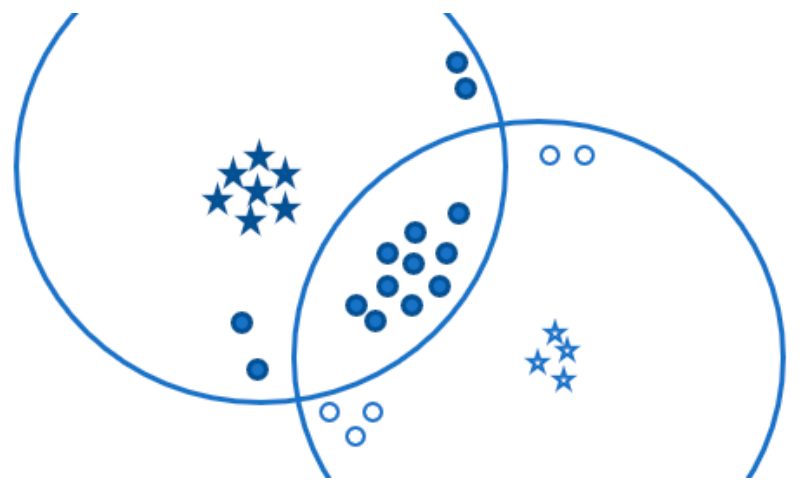

Figure 3. Integrated framework for studying discursive regime destabilisation applied to the ECG case study. Stars represent core actors and dots represent aligned actors.

\section{Discussion: Destabilisation Phases and Enabling Factors}

In the studied case of a socio-economic transition in the making, we can still observe actors who have a strong commitment to the regime and exclusively diffuse frames to protect the regime. For instance, the Austrian Chamber of Commerce and the Styrian Chamber of Commerce, which diffused the Profit-Driven Economy and Business Threat frames, are still in the first phase of destabilisation-Blindness and Denial.

Although core regime actors are rather consistent in their critique of the ECG, several aligned regime actors support the ECG's claims. For instance, some economists diffuse the Malfunctioning Economic System frame, which supports the message about performance problems within the regime; 
and the EESC diffuses claims underpinning the Economic Opportunity and New Market Economy niche frames. This lack of unity demonstrates that the regime has lost commitment from some actors and signals that the second phase of regime destabilisation-Incremental Responses to Problem—has been reached.

This study was not designed to be longitudinal, so it did not capture whether regime actors changed their discourse over time. However, the evidence provided by interviewees allows some reflection on the dynamics within the discourse. For instance, companies report that their efforts in overcoming the challenges of the regime have brought some results: existing customers have become more supportive of an ecological vision, new customers have appeared and suppliers provided more sustainable alternatives (Respondent \#11, personal communication, 30 May 2018; Respondent \#14, personal communication, 9 June 2018; Respondent \#15, personal communication, 18 June 2018). Furthermore, in seven years, about 400 companies implemented the CGBS. Christian Felber has even suggested that one or a few companies listed on the Frankfurt stock exchange are considering adopting the CGBS (personal communication, 20 May 2018). This development demonstrates that frames used by the ECG have caused some regime actors to adopt some niche ideas and move to the space of mutual alignment not just in framing, but also in operational dimension. Therefore, companies that, while implementing CGBS, still reproduce elements of the regime and adhere to its dominant practices, are in the third phase of destabilisation-Increasing Doubts and Diversification.

Some actors are classified as belonging to either the niche's periphery (e.g., Greenpeace Germany, one organic gardener, two sustainability consultants) or core (e.g., people actively managing the ECG). However, as their previous relationship with the regime was not documented, we abstained from making claims about the unfolding fourth phase of destabilisation (so niche actors have a different visual representation in Figure 3).

What are the factors that contribute to the regime destabilisation described above? The framing analysis confirms that niche-regime interactions are a complex dynamic. When the regime resists the niche, it creates challenges to the ECG (e.g., undermined legitimacy, lack of active shielding), but it also creates incentives for it to develop (e.g., by improving existing frames or creating new ones). In the case of the ECG, the niche actors are aware of the challenges and opportunities and try to make use of them. Niche actors indirectly and directly debunk the regime's frames (thus undermining its legitimacy) by raising awareness and initiating and supporting debate about desired systemic changes. The ECG is also building a strong case around its own ideas through the following activities: diffusing an appealing vision of an alternative system; presenting a useful tool that can connect societal actors to the niche; providing evidence that niche ideas are economically feasible; and in general, diffusing consistent niche framing. Although the niche has no response to the Scientific Uncertainty regime frame, it does have another advantage. ECG actors employ all three types of frames (with a clear emphasis on prognostic and motivational frames), while the regime does not use prognostic frames at all. This asymmetry puts the ECG in a more favourable position, as the ECG does not lose out on the power of a positive story.

\section{Conclusions}

The aims of this article were: (1) to develop a novel analytical framework for studying the discursive regime destabilisation based on the previous work by Turnheim and Geels [19] and Rosenbloom [27]; and (2) to apply it to a case of a socio-economic transition-in-the-making to advance research on the topic of socio-economic transformation. The framework proved to be useful for analysing the chosen case study of the ECG and showed that the motivational and prognostic frames of the niche about the alternative economic model are mostly opposed by diagnostic regime frames. We identified three phases of discursive destabilisation unfolding in the case of the ECG: Blindness and Denial, Incremental Responses to Problems and Increasing Doubts and Diversification.

The framing strategies employed by the niche have a different impact on different types of actors. Representatives of high authorities, for instance, remain in the first phase of destabilisation, 
while regional authorities, NGOs and private companies are already at the second and third phases. The latter group questions the current economic system that functions under imperatives of perpetual growth and profit-seeking, though in the discourse they are mainly focusing on positive visioning of an economic model for the future which changes the purpose of the economy from financial gain to other values such as dignity, solidarity, ecological sustainability, social justice, transparency and democracy.

This research has several implications. First, it allows making a tentative conclusion about bottom-up directionality of discursive destabilisation. This directionality means that niche actors, who aim to advance sustainability transformation, should especially concentrate their efforts on non-governmental organisations, small and medium enterprises, and local authorities. Second, drawing on the understanding of key leverage points for system transformation from Meadows [58], we suggest that the ECG managed to advance discursive destabilisation because it focused, among other things, on the goals of the economic system and the mind-sets that support it. Third, based on the case-study results, one can speculate about strategies that hinder and speed up discursive destabilisation. Regime actors are likely to diffuse frames that defend the status-quo and posit that necessary transformation can be achieved with incremental changes to business-as-usual practices. Regime actors also tend to actively delegitimise alternatives that undermine their interests. Niche actors, therefore, should be ready to deal with these challenges to make the sustainability transformation happen. Diffusion of predominantly diagnostic frames-which is happening, for example, through the acts of civil disobedience by Extinction Rebellion, protests by students across and beyond Europe, and IPCC reports-is not enough. A successful discursive strategy would contain a mix of motivational, prognostic and diagnostic frames. Because "changing the way we see the world also changes the way we are in the world" [23], niche actors should explain concrete benefits of alternatives they suggest and, importantly, find ways to translate their discourse into specific solutions. In this respect, CGBS employed by the ECG proved to be a useful tool in uniting a diverse set of actors. All the aforementioned strategies can support societal or policy efforts to accelerate sustainability transformations, however, further research is necessary to test wider applicability of these conclusions.

The findings of this article are based on qualitative research methods, and a limited number of people could be reached for interviews and survey participation. The chronology of the framing interactions covered the last seven years and was primarily focused on identifying the key frames of regime and niche actors. Causal relations between niche and regime claims were not studied in great detail. The results presented in this article should therefore be perceived as a "snapshot" of the niche-regime framing interaction. We also want to be cautious in making premature conclusions about the level to which the ECG leads the search for alternatives to the established socio-economic regime.

Given the urgency of the environmental crisis and its deep connection with the growth-centred cognitive framework, research on socio-economic transformations and, in particular, the discursive destabilisation of capitalist-growth regime bears important implications for practice and theory alike. To further develop this line of work, we suggest employing the analytical framework developed in this paper for studying other cases, either ongoing or historical. The framework is useful as, on the one hand, it allows an appropriate level of detail to identify the actors advancing discursive destabilisation and the framing strategies that help them with this task. On the other hand, the framework allows capturing discursive resistance put up by regime actors and their framing strategies. Furthermore, the more systematic approach to studying discursive regime destabilisation offered by the framework could prove useful in exploring dynamics between discursive destabilisation and destabilisation of routines and practices.

Our case study of the ECG has demonstrated that we are already witnessing discursive destabilisation signs in different European countries. A more systematic comparison across them could be performed to map regime resistance patterns and destabilisation processes on a transnational level. Such a research endeavour would help to overcome the implicit methodological nationalism of most transition studies-related research [59]. It might also have implications for policy-making as the 
acknowledged existence of an international socio-economic regime would require coordinated efforts in supporting niche activities.

Author Contributions: Conceptualisation, O.V. and C.S.; methodology, O.V. and C.S.; formal analysis, O.V.; investigation, O.V.; data curation, O.V.; writing-original draft preparation, O.V.; writing-review and editing, O.V. and C.S.; visualisation, O.V.; and supervision, C.S.

Funding: This research received no external funding.

Acknowledgments: We wish to thank the anonymous reviewers for their constructive criticism of earlier versions of the paper. The authors thank all of the informants who kindly provided their time for the interviews, as well as everyone who helped to organise interviews with the ECG members.

Conflicts of Interest: The authors declare no conflict of interest.

\section{Appendix A}

Table A1. Core and aligned actors identified for the ECG case study.

\begin{tabular}{|c|c|c|}
\hline & Core Actors & Aligned Actors \\
\hline Regime & $\begin{array}{l}\text { Austrian Federal Economic Chamber; Styrian } \\
\text { Chamber of Commerce; Randolf Rodenstock, } \\
\text { chairman of the Roman Herzog Institute; } \\
\text { Dr. Hans Schimpfhauser, district chairman of } \\
\text { the Independent Voter Community Rottal-Inn; } \\
\text { Erhard Fürst, ex-chief economist of the } \\
\text { Austrian Federation of Industrialists; } \\
\text { Timo Meynhardt, German psychologist and } \\
\text { business economist, managing director of the } \\
\text { Center for Leadership and Values in Society at } \\
\text { the University of St. Gallen; Thomas Eisenreich, } \\
\text { Business Unit Manager for the Association of } \\
\text { Diaconal Employers in Germany. }\end{array}$ & $\begin{array}{l}\text { Dirk Löhr, German economist; } \\
\text { René Schmidpeter. director of the Centre for } \\
\text { Humane Market Economy in Salzburg; } \\
\text { Harald Mahrer, ex-president of Julius Raab } \\
\text { Stiftung, president of the Austrian Economic } \\
\text { Chamber; The European Economic and Social } \\
\text { Committee (EESC); Antje von Dewitz, chief } \\
\text { executive Vaude; Satis\&Fy, provider of event } \\
\text { and media technology; Heinrich Kronbichler, } \\
\text { CEO of WBS Training AG; Johannes Gutmann, } \\
\text { managing director Sonnentor; etc. }\end{array}$ \\
\hline Niche & $\begin{array}{l}\text { Matt Mayer, Director of the ECG UK; } \\
\text { Christian Felber, initiator of the ECG and the } \\
\text { project "Bank for the common good"; } \\
\text { Marta Avesani, business consultant; } \\
\text { Andy Chapman, director of the ECG UK. }\end{array}$ & $\begin{array}{l}\text { Anke Winchenbach, ECG UK consultant, } \\
\text { Associate Lecturer and PhD Researcher at } \\
\text { University of Surrey; Greenpeace Germany; } \\
\text { Pedro Olazabal, CSR and Sustainability } \\
\text { consultant; Lisa Muhr, co-founder and } \\
\text { co-managing director of Göttin des Glücks, } \\
\text { an eco-friendly Austrian fashion label; } \\
\text { Dr. Wolfgang Kessler, economist and publicist; } \\
\text { Antje von Dewitz, chief executive Vaude; } \\
\text { Sparda-Bank Munich; Andreas Huber, lecturer, } \\
\text { CEO of the German Society Club of Rome and } \\
\text { honorary board of the Desertec Foundation; } \\
\text { Harro Colshorn, organic gardener; Anna } \\
\text { Deparnay-Grunenberg, group leader for the } \\
\text { city of Stuttgart for the Greens; Melissa Scanlan, } \\
\text { Associate Dean, co-founder of the New } \\
\text { Economy Law Center; Renate Künast, Green } \\
\text { politician and former Minister of Consumer } \\
\text { Protection, Food and Agriculture in Germany; } \\
\text { Government of Valencia; Johannes Gutmann; } \\
\text { Satis\&Fy; Heinrich Kronbichler. }\end{array}$ \\
\hline
\end{tabular}




\section{Appendix B}

Table A2. Analytical matrix for ECG case study.

\begin{tabular}{|c|c|c|c|c|c|c|c|c|}
\hline Aligned Actors & Core Actors & Key Claims & Regime Frame & & Niche Frame & Key Claims & Core Actors & Aligned Actors \\
\hline H. Mahrer & $\begin{array}{c}\text { Austrian } \\
\text { Chamber of } \\
\text { Commerce; } \\
\text { R. Rodenstock; } \\
\text { H. Schimpfhauser }\end{array}$ & $\begin{array}{ll}\text { - } & \text { Enormous wealth has } \\
\text { been created. } \\
\text { - Competition leads to } \\
\text { growth and prosperity. } \\
\text { The current economic } \\
\text { system works well. }\end{array}$ & $\begin{array}{c}\text { Socio-Economic } \\
\text { Progress }\end{array}$ & $\Rightarrow \Leftarrow$ & $\begin{array}{l}\text { Malfunctioning } \\
\text { Economic } \\
\text { System }\end{array}$ & $\begin{array}{l}\text { The current economic } \\
\text { system creates a } \\
\text { number of serious } \\
\text { problems: } \\
\text { unemployment, } \\
\text { poverty, exclusion, } \\
\text { climate change } \\
\text { The problem is an } \\
\text { orientation to growth. } \\
\text { Neoliberal capitalism is } \\
\text { not aligned with what } \\
\text { people want. } \\
\text { Wealth is very } \\
\text { unevenly distributed. }\end{array}$ & $\begin{array}{l}\text { M. Mayer; } \\
\text { C. Felber; } \\
\text { M. Avesani }\end{array}$ & $\begin{array}{c}\text { M. Scanla; } \\
\text { Greenpeace Germany; } \\
\text { A. Winchenbach; } \\
\text { L. Muhr; Dr. W. Kessler; } \\
\text { D. Löhr; W. Schweizer; } \\
\text { R. Schmidpeter }\end{array}$ \\
\hline $\begin{array}{l}\text { H. Mahrer; } \\
\text { R. Schmidpeter }\end{array}$ & $\begin{array}{l}\text { Styrian Chamber } \\
\text { of Commerce }\end{array}$ & 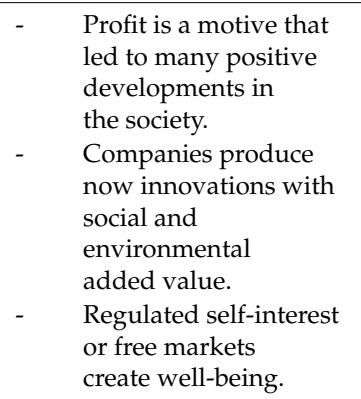 & $\begin{array}{l}\text { Profit-Driven } \\
\text { Economy }\end{array}$ & $\Rightarrow \Leftarrow$ & $\begin{array}{l}\text { Ethical } \\
\text { Economy }\end{array}$ & $\begin{array}{l}\text { Enterprises must take } \\
\text { responsibility for } \\
\text { their actions. } \\
\text { Companies should live } \\
\text { such values as } \\
\text { cooperation and } \\
\text { appreciation of man } \\
\text { and nature. } \\
\text { The economy should be } \\
\text { based on } \\
\text { universal values. }\end{array}$ & $\begin{array}{l}\text { M. Mayer; } \\
\text { C. Felber; } \\
\text { M. Avesani }\end{array}$ & $\begin{array}{c}\text { A. von Dewitz; } \\
\text { Sparda-Bank Munich; } \\
\text { H. Kronbichler; } \\
\text { Dr. W. Kessler; } \\
\text { R. Künast; A. } \\
\text { Deparnay-Grunenberg; } \\
\text { P. Olazabal; } \\
\text { Government of } \\
\text { Valencia; Greenpeace } \\
\text { Germany; W. Schweizer }\end{array}$ \\
\hline $\begin{array}{l}\text { R. Schmidpeter; } \\
\text { H. Mahrer; } \\
\text { D. Löhr. }\end{array}$ & $\begin{array}{l}\text { Styrian Chamber } \\
\text { of Commerce }\end{array}$ & $\begin{array}{l}\text { ECG does not } \\
\text { formulate a } \\
\text { new alternative. } \\
\text { ECG packs the ideas of } \\
\text { Marxism into } \\
\text { new phrases. }\end{array}$ & $\begin{array}{l}\text { Old Socialist } \\
\text { Ideas }\end{array}$ & $\Rightarrow \Leftarrow$ & $\begin{array}{l}\text { New Market } \\
\text { Economy }\end{array}$ & $\begin{array}{ll} & \text { ECG calls for a new } \\
\text { economic system. } \\
\text { It is a complete and } \\
\text { consistent alternative to } \\
\text { global capitalism. } \\
\text { ECG operates without } \\
\text { falling back into the } \\
\text { historical extremes of } \\
\text { capitalism } \\
\text { and communism. }\end{array}$ & $\begin{array}{l}\text { C. Felber; } \\
\text { A. Chapman }\end{array}$ & $\begin{array}{l}\text { Government of } \\
\text { Valencia; Greenpeace } \\
\text { Germany; H. Colshorn; } \\
\text { EESC; M. Scanlan; } \\
\text { W. Schweizer }\end{array}$ \\
\hline
\end{tabular}


Table A2. Cont.

\begin{tabular}{|c|c|c|c|c|c|c|c|c|}
\hline Aligned Actors & Core Actors & Key Claims & Regime Frame & & Niche Frame & Key Claims & Core Actors & Aligned Actors \\
\hline $\begin{array}{c}\text { H. Mahrer; } \\
\text { N. Paech; } 140 \\
\text { Austrian } \\
\text { economists }\end{array}$ & $\begin{array}{l}\text { T. Meynhardt; } \\
\text { R. Rodenstock }\end{array}$ & $\begin{array}{ll}\text { - } & \text { ECG is based on } \\
\text { normative statements. } \\
\text { ECG has no sound } \\
\text { theoretical background. } \\
\text { ECG is based on a } \\
\text { contradictory and very } \\
\text { populist analysis. }\end{array}$ & $\begin{array}{l}\text { Scientific } \\
\text { Uncertainty }\end{array}$ & $\Rightarrow$ & $\begin{array}{l}\text { No } \\
\text { corresponding } \\
\text { frame }\end{array}$ & & & \\
\hline $\begin{array}{c}\text { Various } \\
\text { companies; } \\
\text { Harald Mahrer }\end{array}$ & $\begin{array}{l}\text { Austrian } \\
\text { Chamber of } \\
\text { Commerce; } \\
\text { T. Eisenreich }\end{array}$ & $\begin{array}{l}\text { CGBS is far } \\
\text { too regulatory. } \\
\text { It is immensely } \\
\text { complex accounting. } \\
\text { The values of CGBS } \\
\text { will be imposed } \\
\text { on companies. }\end{array}$ & $\begin{array}{l}\text { Imposed } \\
\text { Sustainability } \\
\text { Reporting }\end{array}$ & $\Rightarrow \Leftarrow$ & $\begin{array}{c}\text { Useful } \\
\text { Sustainability } \\
\text { Reporting }\end{array}$ & $\begin{array}{l}\text { CGBS enables any } \\
\text { organisation to } \\
\text { evaluate its impact. } \\
\text { Tool for self-assessment } \\
\text { and } \\
\text { continuous development. } \\
\text { A feasible tool which } \\
\text { can be used by every } \\
\text { actor of } \\
\text { contemporary society. }\end{array}$ & $\begin{array}{l}\text { A. Chapman; } \\
\text { M. Avesani; } \\
\text { C. Felber }\end{array}$ & $\begin{array}{l}\text { Sparda-Bank Munich; } \\
\text { J. Gutmann; EESC; } \\
\text { Business School } \\
\text { Lausanne; Vaude; } \\
\text { L. Muhr; Satis\&Fy; } \\
\text { surveyed companies; } \\
\text { W. Schweizer; } \\
\text { Government of } \\
\text { Valencia }\end{array}$ \\
\hline $\begin{array}{l}\text { H. Mahrer; } \\
\text { D. Löhr }\end{array}$ & $\begin{array}{l}\text { Austrian } \\
\text { Chamber of } \\
\text { Commerce; } \\
\text { T. Eisenreich; } \\
\text { R. Rodenstock; } \\
\text { E. Fürst }\end{array}$ & $\begin{array}{l}\text { ECG restricts freedom } \\
\text { by suggesting } \\
\text { maximum income. } \\
\text { What should or should } \\
\text { not be produced is } \\
\text { determined from } \\
\text { the top. } \\
\text { Minimisation of } \\
\text { competition can lead to } \\
\text { a "common good } \\
\text { dictatorship". }\end{array}$ & $\begin{array}{l}\text { Common Good } \\
\text { Dictatorship }\end{array}$ & $\Rightarrow \Leftarrow$ & $\begin{array}{c}\text { Expression of } \\
\text { Public Will }\end{array}$ & 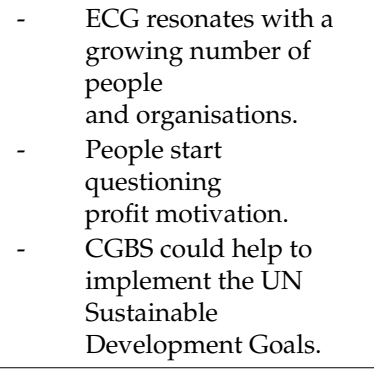 & $\begin{array}{l}\text { C. Felber; } \\
\text { M. Mayer }\end{array}$ & $\begin{array}{c}\text { A. Winchenbach; } \\
\text { A. Huber; A. } \\
\text { Deparnay-Grunenberg; } \\
\text { EESC }\end{array}$ \\
\hline H. Mahrer & $\begin{array}{l}\text { Austrian } \\
\text { Chamber of } \\
\text { Commerce; } \\
\text { E. Fürst }\end{array}$ & $\begin{array}{l}\text { - } \quad \text { CGBS increases the } \\
\text { costs of doing business. } \\
\text { Production processes } \\
\text { will become inefficient } \\
\text { and expensive. } \\
\text { Austria will fall out of } \\
\text { the international } \\
\text { economic grid. }\end{array}$ & Business Threat & $\Rightarrow$ & $\begin{array}{l}\text { Economic } \\
\text { Opportunity }\end{array}$ & $\begin{array}{ll}\text { - } & \text { ECG will foster social } \\
\text { innovation and benefit } \\
\text { the environment. } \\
\text { CGBS does not threaten } \\
\text { jobs and profits. } \\
\text { The value-based } \\
\text { economy can still } \\
\text { produce financial or } \\
\text { GDP growth. }\end{array}$ & $\begin{array}{l}\text { M. Mayer, } \\
\text { C. Felber }\end{array}$ & $\begin{array}{c}\text { EESC; L. Muhr; } \\
\text { Sparda-Bank Munich; } \\
\text { Hotel La Perla; } \\
\text { W. Schweizer }\end{array}$ \\
\hline
\end{tabular}




\section{References}

1. Raskin, P.; Banuri, T.; Gallopin, G.; Gutman, P.; Hammond, A.; Kates, R.; Swart, R. Great transition. Umbrüche und Übergänge auf dem Weg zu einer planetarischen Gesellschaft. Mater. Soz. Ökologie 2002, 20. Available online: http://www.isoe-publikationen.de/fileadmin/redaktion/ISOE-Reihen/msoe/msoe-20-isoe-2003.pdf (accessed on 2 June 2018).

2. Daly, H.E.; Cobb, J.B. For the Common Good: Redirecting the Economy Toward Community, the Environment, and a Sustainable Future; Beacon Press: Boston, MA, USA, 1994.

3. Jackson, T.; Victor, P. Productivity and work in the 'green economy':Some theoretical reflections and empirical tests. Environ. Innov. Soc. Transit. 2011, 1, 101-108. [CrossRef]

4. Petridis, P.; Muraca, B.; Kallis, G. Degrowth: between a scientific concept and a slogan for a social movement. In Handbook of Ecological Economics; Edward Elgar Publishing: Cheltenham, UK, 2015; pp. 176-200.

5. D'Alisa, G.; Demaria, F.; Kallis, G. Degrowth: A Vocabulary for a New Era; Routledge: Abingdon, UK, 2014.

6. Kemp, R.; Weaver, P.M.; Strasser, T.; Backhaus, J.; Golland, A. Socio-economic transformations: Insights for sustainability. In Perspectives on Transitions to Sustainability; Publications Office of the European Union: Luxembourg, 2018.

7. Berlo, K.; Wagner, O.; Heenen, M. The Incumbents' Conservation Strategies in the German Energy Regime as an Impediment to Re-Municipalization-An Analysis Guided by the Multi-Level Perspective. Sustainability 2016, 9, 53. [CrossRef]

8. Fuenfschilling, L.; Truffer, B. The interplay of institutions, actors and technologies in socio-technical systems-An analysis of transformations in the Australian urban water sector. Technol. Forecast. Soc. Chang. 2016, 103, 298-312. [CrossRef]

9. Geels, F. Technological transitions as evolutionary reconfiguration processes: A multi-level perspective and a case-study. Res. Policy 2002, 31, 1257-1274. [CrossRef]

10. Raven, R.P. Towards alternative trajectories? Reconfigurations in the Dutch electricity regime. Res. Policy 2006, 35, 581-595. [CrossRef]

11. Geels, F.; Kern, F.; Fuchs, G.; Hinderer, N.; Kungl, G.; Mylan, J.; Neukirch, M.; Wassermann, S. The enactment of socio-technical transition pathways: A reformulated typology and a comparative multi-level analysis of the German and UK low-carbon electricity transitions (1990-2014). Res. Policy 2016, 45, 896-913. [CrossRef]

12. Geels, F. From sectoral systems of innovation to socio-technical systems: Insights about dynamics and change from sociology and institutional theory. Res. Policy 2004, 33, 897-920. [CrossRef]

13. Feola, G. Capitalism in sustainability transitions research: Time for a critical turn? Environ. Innov. Soc. Transit. 2019. [CrossRef]

14. Vandeventer, J.S.; Cattaneo, C.; Zografos, C. A Degrowth Transition: Pathways for the Degrowth Niche to Replace the Capitalist-Growth Regime. Ecol. Econ. 2019, 156, 272-286. [CrossRef]

15. STRN. A Research Agenda for the Sustainability Transitions Research Network; Sustainable Consumption Institute, University of Manchester: Manchester, UK, 2017.

16. Kungl, G.; Geels, F.W. Sequence and alignment of external pressures in industry destabilisation: Understanding the downfall of incumbent utilities in the German energy transition (1998-2015). Environ. Innov. Soc. Transit. 2018, 26, 78-100. [CrossRef]

17. Matschoss, K.; Heiskanen, E. Innovation intermediary challenging the energy incumbent: Enactment of local socio-technical transition pathways by destabilisation of regime rules. Technol. Anal. Strateg. Manag. 2018, 30, 1455-1469. [CrossRef]

18. Hoffmann, S.; Weyer, J.; Longen, J. Discontinuation of the automobility regime? An integrated approach to multi-level governance. Transp. Res. Part A Policy Pract. 2017, 103, 391-408. [CrossRef]

19. Turnheim, B.; Geels, F. Regime destabilisation as the flipside of energy transitions: Lessons from the history of the British coal industry (1913-1997). Energy Policy 2012, 50, 35-49. [CrossRef]

20. Martínez Arranz, A. Lessons from the past for sustainability transitions? A meta-analysis of socio-technical studies. Glob. Environ. Chang. 2017, 44, 125-143. [CrossRef]

21. Kuokkanen, A.; Nurmi, A.; Mikkilä, M.; Kuisma, M.; Kahiluoto, H.; Linnanen, L. Agency in regime destabilization through the selection environment: The Finnish food system's sustainability transition. Res. Policy 2018, 47, 1513-1522. [CrossRef] 
22. Bosman, R.; Loorbach, D.; Rotmans, J.; van Raak, R. Carbon Lock-Out: Leading the Fossil Port of Rotterdam into Transition. Sustainability 2018, 10, 2558. [CrossRef]

23. Göpel, M. The Great Mindshift: How a New Economic Paradigm and Sustainability Transformations Go Hand in Hand; Springer: Berlin/Heidelberg, Germany, 2016; Volume 2.

24. Scholl, C.; Freyberg-Inan, A. Hegemony's dirty tricks: Explaining counter-globalization's weakness in times of neoliberal crisis. Globalizations 2013, 10, 619-634. [CrossRef]

25. Purdey, S.J. Economic Growth, the Environment and International Relations: The Growth Paradigm; Routledge: Abingdon, UK, 2010.

26. Kallis, G.; Kostakis, V.; Lange, S.; Muraca, B.; Paulson, S.; Schmelzer, M. Research on degrowth. Annu. Rev. Environ. Resour. 2018, 43, 291-316. [CrossRef]

27. Rosenbloom, D. Framing low-carbon pathways: A discursive analysis of contending storylines surrounding the phase-out of coal-fired power in Ontario. Environ. Innov. Soc. Transit. 2018, 27, 129-145. [CrossRef]

28. Roberts, J. Discursive destabilisation of socio-technical regimes: Negative storylines and the discursive vulnerability of historical American railroads. Energy Res. Soc. Sci. 2017, 31, 86-99. [CrossRef]

29. Druckman, J.N. Political preference formation: Competition, deliberation, and the (ir) relevance of framing effects. Am. Political Sci. Rev. 2004, 98, 671-686. [CrossRef]

30. Geels, F. The impact of the financial-economic crisis on sustainability transitions: Financial investment, governance and public discourse. Environ. Innov. Soc. Transit. 2013, 6, 67-95. [CrossRef]

31. Gough, I. Economic crisis, climate change and the future of welfare states. Twenty-First Century Soc. 2010, 5, 51-64. [CrossRef]

32. Melucci, A. The symbolic challenge of contemporary movements. Soc. Res. 1985, 52, 789.

33. Eyerman, R.; Jamison, A. Social Movements: A Cognitive Approach; Polity Press: Cambridge, UK, 1991.

34. Della Porta, D.; Diani, M. Social Movements: An Introduction; John Wiley \& Sons: Hoboken, NJ, USA, 2009.

35. Rotmans, J.; Kemp, R.; Van Asselt, M. More evolution than revolution: Transition management in public policy. Foresight 2001, 3, 15-31. [CrossRef]

36. McCarthy, J.D.; Zald, M.N. Resource mobilization and social movements: A partial theory. Am. J. Sociol. 1977, 82, 1212-1241. [CrossRef]

37. ECG. Community. 2017. Available online: https://www.ecogood.org/en/community/ (accessed on 16 February 2018).

38. ECG. Local Chapters. 2018. Available online: https://www.ecogood.org/en/community/local-chapters/ (accessed on 16 February 2018).

39. Soderbaum, P. Understanding Sustainability Economics: Towards Pluralism in Economics; Routledge: Abingdon, UK, 2012.

40. Felber, C.; Nurmi, S.; Maskin, E. Change Everything: Creating an Economy for the Common Good; Zed Books: London, UK, 2015.

41. ECG. Vision. 2017. Available online: https://www.ecogood.org/en/vision/ (accessed on 16 July 2018).

42. Blachfellner, M.; Drosg-Plöckinger, A.; Fieber, S.; Hofielen, G.; Knakrügge, L.; Kofranek, M.; Koloo, S. Workbook. Full Balance Sheet 5.0. Matrix Development Team, 2017. Available online: https://www.ecogood.org/media/filer_ public/5d/4d/5d4d17bc-156b-44ec-9115-fe6b37c63187/ecg_compact_balance_sheet_workbook.pdf (accessed on 10 June 2018).

43. Felber, C. Gemeinwohl-Ökonomie. Eine Demokratische Alternative Wächst; Deuticke im Paul Zsolnay Verlag: Wien, Austria, 2016.

44. Felber, C. Stellungnahme Petition Lehrbuch. 2016. Available online: https://www.christian-felber.at/schaetze/ Stellungnahme_PetitionLehrbuch_Felber_042016.pdfs (accessed on 5 August 2018).

45. Steigenberger, K. Gemeinwohlökonomie am Prüfstan. Eine Umfassende und kritische Analyse; Wirtschaftskammer Österreich: Vienna, Austria, 2013; Available online: https://news.wko.at/news/oesterreich/Dossier_2013-08_ Gemeinwohloekonomie.pdf (accessed on 20 July 2018).

46. Mahrer, H. Anschlag auf Unseren Wohlstand? Wie Die Gemeinwohl-Ökonomie Unsere Soziale Marktwirtschaft Zerstören Will; Julius Raab Stiftung: Vienna, Austria, 2012; Available online: https://www.ecogood.org/media/filer_public/ 0c/01/0c01c6f9-2c26-47e5-9479-0d102ca20b30/negativkampagnenbroschure_julius-raab-stiftung.pdf (accessed on 25 July 2018). 
47. Badinger, H.; Berger, U.; Böheim, R.; Cuaresma, J.; Oliver, F.; Fürnkranz-Prskawetz, A.; Gugler, K.; Hof, F.; Hofer, H.; Kaniovski, S.; et al. Offener Brief an das Bundesministerium für Bildung und Frauen. 2016. Available online: http://scienceblogs.de/kritisch-gedacht/2016/04/07/christian-felber-alswirtschaftstheoretiker-im-schulbuch-ein-offener-brief/ (accessed on 5 August 2018).

48. Smith, A.; Voß, J.-P.; Grin, J. Innovation studies and sustainability transitions: The allure of the multi-level perspective and its challenges. Res. Policy 2010, 39, 435-448. [CrossRef]

49. Hermans, F.; Horlings, I.; Beers, P.J.; Mommaas, H. The contested redefinition of a sustainable countryside: Revisiting frouws' rurality discourses. Sociol. Rural. 2010, 50, 46-63. [CrossRef]

50. Geels, F. Regime Resistance against Low-Carbon Transitions: Introducing Politics and Power into the Multi-Level Perspective. Theory Cult. Soc. 2014, 31, 21-40. [CrossRef]

51. Geels, F. The multi-level perspective on sustainability transitions: Responses to seven criticisms. Environ. Innov. Soc. Transit. 2011, 1, 24-40. [CrossRef]

52. Geels, F. Reconceptualising the co-evolution of firms-in-industries and their environments: Developing an inter-disciplinary Triple Embeddedness Framework. Res. Policy 2014, 43, 261-277. [CrossRef]

53. Rosenbloom, D.; Berton, H.; Meadowcroft, J. Framing the sun: A discursive approach to understanding multi-dimensional interactions within socio-technical transitions through the case of solar electricity in Ontario, Canada. Res. Policy 2016, 45, 1275-1290. [CrossRef]

54. Snow, D.A.; Benford, R.D. Master frames and cycles of protest. Front. Soc. Mov. Theory 1992, $133,155$.

55. Benford, R.D.; Snow, D.A. Framing Processes and Social Movements: An Overview and Assessment. Annu. Rev. Sociol. 2000, 26, 611-639. [CrossRef]

56. European Economic and Social Committee. Opinion of the Economic and Social Committee on 'The Economy for the Common Good: A Sustainable Economic Model Geared towards Social Cohesion' (Own-Initiative Opinion). 2015. Available online: https://www.eesc.europa.eu/en/our-work/opinions-information-reports/ opinions/economy-common-good (accessed on 22 June 2018).

57. Löhr, D. Gemeinwohlökonomie: Robespierre Lässt Grüssen. 2014. Available online: https://bodenwertsteuer. org/2014/09/08/gemeinwohlokonomie-robespierre-lasst-grusen/ (accessed on 8 June 2018).

58. Meadows, D.H. Leverage Points: Places to Intervene in a System; The Sustainability Institute: Hartland, VT, USA, 1999.

59. Fuenfschilling, L.; Binz, C. Global socio-technical regimes. Res. Policy 2018, 47, 735-749. [CrossRef]

(C) 2019 by the authors. Licensee MDPI, Basel, Switzerland. This article is an open access article distributed under the terms and conditions of the Creative Commons Attribution (CC BY) license (http://creativecommons.org/licenses/by/4.0/). 